\title{
Direct thrombolysis for cerebral venous sinus thrombosis
}

\author{
Maryam Rahman, M.D., Gregory J. Velat, M.D., Brian L. Hoh, M.D., \\ AND J Mocco, M.D., M.S. \\ Department of Neurosurgery, University of Florida, Gainesville, Florida
}

\begin{abstract}
Cerebral venous sinus thrombosis (CVST) is an increasingly diagnosed disease with a wide range of symptoms, ranging from a mild headache to cerebral herniation. A potentially devastating syndrome, CVST has been associated with a mortality rate of 6-10\%. In prospective studies, the overall rate of death and dependency from CVST ranges from 8.8 to $44.4 \%$. Systemic anticoagulation remains the first-line treatment. However, a percentage of patients deteriorate despite medical therapy. These cases have resulted in the development of thrombolysis or endovascular treatment for CVST. Initial reports of the use of endovascular treatment of CVST have been promising. However, enthusiasm for the use of endovascular thrombolysis and thrombectomy should be tempered by an understanding of possible risks such as intracerebral hemorrhage and/or vessel dissection. The authors review the literature regarding endovascular treatment of CVST with a description of the chemical and mechanical thrombolytic techniques. (DOI: 10.3171/2009.7.FOCUS09146)
\end{abstract}

\section{Key Words • cerebral venous sinus thrombosis • endovascular thrombolysis - mechanical thrombectomy}

$\mathrm{C}$ EREBRAL venous sinus thrombosis manifests with a spectrum of signs and symptoms ranging from a mild headache to herniation from intracranial hypertension. ${ }^{16,18}$ Traditionally, CVST was considered an uncommon disorder. ${ }^{6,27}$ However, with improvements in imaging and increased awareness, CVST has been reported more often. $4,34,89$

In contrast to previous thinking, CVST is not a benign diagnosis and is associated with a mortality rate of $6-10 \%{ }^{16,63}$ In prospective studies, the overall rate of death and dependency due to CVST ranges from 8.8 to $44.4 \%{ }^{32,34,76}$ The possibility of serious morbidity and mortality drives the need for timely diagnosis and treatment of CVST. Systemic anticoagulation is the first-line treatment. The majority of patients with CVST will respond to systemic anticoagulation. However, a percentage of patients either deteriorate despite medical therapy or present with dramatic symptoms that require emergent intervention. These cases have resulted in the development of thrombolysis ${ }^{24,36,60,65,88,91}$ or endovascular treatment for CVST.

With new endovascular techniques and devices, direct thrombolysis and thrombectomy without a craniotomy is becoming increasingly common. ${ }^{70,80}$ Endovascular treatment of CVST has the potential advantages of acute dissolution of clot, allowing normalization of blood flow, decreased ICP, and rapid improvement of severe symp-

\footnotetext{
Abbreviations used in this paper: $\mathrm{CVST}=$ cerebral venous sinus thrombosis; GCS = Glasgow Coma Scale; ICH = intracranial hemorrhage; ICP = intracranial pressure; $\mathrm{RCT}=$ randomized controlled trial; $\mathrm{tPA}=$ tissue plasminogen activator.
}

toms. Conversely, these invasive procedures are also associated with risks such as hemorrhage, vessel dissection, and pulmonary embolism. ${ }^{24,91}$ We review the techniques and indications for endovascular treatment of CVST.

\section{Methods}

We searched the PubMed database for Englishlanguage literature published between 1950 and 2009 regarding CVST, thrombolysis, and endovascular treatment. The results of this search as well as relevant references from the publications reviewed were subsequently categorized as direct thrombolysis or mechanical thrombolysis/thrombectomy.

\section{Results}

The search revealed 71 original publications regarding endovascular treatment of CVST - 51 with only direct chemical thrombolysis (Table 1) and 20 with chemical and/or mechanical thrombolysis (Table 2). These publications mostly consist of case reports beginning in 1988 until June 2009. A total of 161 patients underwent direct chemical thrombolysis and 34 patients underwent chemical and mechanical thrombolysis/thrombectomy. This literature is summarized below.

\section{Discussion}

The exact incidence of CVST remains unknown but has been reported to be as high as $9 \%$ in an autopsy 


\section{Rahman et al.}

TABLE 1: Direct thrombolysis for CVST*

\begin{tabular}{|c|c|c|c|c|c|}
\hline Authors \& Year & $\begin{array}{l}\text { No. of } \\
\text { Cases }\end{array}$ & Agent & Dose & Outcome & Age \\
\hline Scott et al., 1988 & 1 & uro & $240,000 \mathrm{U} / \mathrm{hr} \times 3 \mathrm{hrs}, 60,000 \mathrm{U} / \mathrm{hr} \times 8 \mathrm{hrs}$ & neuro improve & adult \\
\hline Higashida et al., 1989 & 1 & uro & $1000 \mathrm{U} / \mathrm{hr} \times 2 \mathrm{hrs}$ & $\begin{array}{l}\text { normal development at } 3 \mathrm{yrs} \\
\text { old }\end{array}$ & child \\
\hline Persson \& Lilja, 1990 & 1 & strepto & $250,000 \mathrm{U} / \mathrm{hr}, 60,000 \mathrm{U} / 6 \mathrm{hrs}, 30,000 \mathrm{U} / 17 \mathrm{hrs}$ & neuro improve & adult \\
\hline Barnwell et al., 1991 & 3 & uro & $58,000 \mathrm{U} / \mathrm{hr} \times 4-10$ days & $\begin{array}{l}\text { clinical improve (1), no improve } \\
\text { (1) }\end{array}$ & adult \\
\hline $\begin{array}{l}\text { Eskridge \& Wess- } \\
\text { becher, } 1991\end{array}$ & 1 & uro & $4000 \mathrm{U} / \mathrm{min} \times 2 \mathrm{hrs}, 1000 \mathrm{U} / \mathrm{min} \times 12 \mathrm{hrs}($ repeated $\times 1)$ & excellent & adult \\
\hline Tsai et al., 1992 & 5 & uro & $200,000-600,000 \mathrm{U}$ & complete neuro recovery in all & adult \\
\hline Smith et al., 1994 & 7 & uro & $20,000-150,000 \mathrm{U} / \mathrm{hr} \times 88-244 \mathrm{hrs}$ & $\begin{array}{l}\text { neuro improve (6), improve after } \\
\text { tx of AVF (1) }\end{array}$ & adult \\
\hline Griesemer et al., 1994 & 1 & uro & $470,000 \mathrm{U} / 75 \mathrm{~min}$ & excellent & ped \\
\hline $\begin{array}{l}\text { Kourtopoulos et al., } \\
1994\end{array}$ & 1 & tPA & $5 \mathrm{mg} / 4 \mathrm{hrs} \times 2$ & neuro improve & adult \\
\hline Barnwell et al., 1995 & 6 & uro & $100,000-\mathrm{U}$ bolus, $40,000-80,000 \mathrm{U} / \mathrm{hr}$ up to $48 \mathrm{hrs}$ & excellent (3), dead (2), blind (1) & both \\
\hline Horowitz et al., 1995 & 12 & uro & $50,000-500,000-\mathrm{U}$ bolus, $73,600 \mathrm{U} / \mathrm{hr} \times 50 \mathrm{hrs}$ & $\begin{array}{l}\text { excellent/good (10), dead (1), } \\
\text { lost to FU (1) }\end{array}$ & both \\
\hline Kermode et al., 1995 & 1 & $\begin{array}{l}\text { uro/ } \\
\text { strepto }\end{array}$ & $\begin{array}{l}\text { uro: } 20,000 \mathrm{U} / \mathrm{hr}, 100,000 \mathrm{U} / 4 \mathrm{hrs} \text {; strepto: 10,000 U/hr × } \\
12 \mathrm{hrs}\end{array}$ & excellent & adult \\
\hline Khoo et al., 1995 & 1 & uro & $400,000 \mathrm{U} / 100 \mathrm{~min}, 120,000 \mathrm{U} / \mathrm{hr} \times 16 \mathrm{hrs}$ & excellent & adult \\
\hline Gebara et al., 1995 & 1 & uro & $25,000 \mathrm{U} / 10 \mathrm{~min} \times 7$ & excellent & child \\
\hline Evans et al., 1996 & 1 & NR & NR & dead & adult \\
\hline Aoki et al., 1997 & 1 & tPA & $1,600,000-U$ bolus & excellent & adult \\
\hline Gerszten et al., 1997 & 1 & uro & $850,000 \mathrm{U} / 3 \mathrm{hrs}$ & excellent & ped \\
\hline Kim \& Suh, 1997 & 9 & tPA & $\begin{array}{l}10 \mathrm{mg} / 10 \mathrm{~min}, 50 \mathrm{mg} / 3 \mathrm{hrs}, 5 \mathrm{mg} / \mathrm{hr} \text { til dose of } 100 \mathrm{mg} / \\
\text { day or complete thrombolysis }\end{array}$ & excellent & adult \\
\hline Rael et al., 1997 & 1 & uro & $250,000-\mathrm{U}$ bolus $\times 2 \mathrm{hrs}, 80,000 \mathrm{U} / \mathrm{hr} \times 165 \mathrm{hrs}$ & excellent & adult \\
\hline Smith et al., 1997 & 2 & uro & $1,000,000 \mathrm{U} / 2 \mathrm{hrs}$ & excellent & adult \\
\hline Spearman et al., 1997 & 2 & uro & $600,000-850,000 \mathrm{U} / 3 \mathrm{hrs}$ & neuro improve & both \\
\hline Holder et al., 1997 & 1 & uro & $\begin{array}{l}150,000-\mathrm{U} \text { bolus, } 100,000 \mathrm{U} / \mathrm{hr} \times 9 \mathrm{hrs}(1 \mathrm{st} \mathrm{tx}), 150,000-\mathrm{U} \\
\text { bolus, } 100,000 \mathrm{U} / \mathrm{hr} \times 48 \mathrm{hrs}\end{array}$ & excellent & adult \\
\hline Renowden et al., 1997 & 1 & tPA & 65 -mg bolus & neuro improve & adult \\
\hline Akai et al., 1997 & 1 & uro & $120,000-U$ bolus & $\begin{array}{l}\text { neuro improve but died of meta- } \\
\text { static melanoma }\end{array}$ & adult \\
\hline D'Alise et al., 1998 & 1 & uro & $500,000-\mathrm{U}$ bolus, $3,000,000 \mathrm{U} / 48 \mathrm{hrs}$ & excellent & adult \\
\hline Kasner et al., 1998 & 3 & uro & $60,000 \mathrm{U} / \mathrm{hr} \times 36-84 \mathrm{hrs}$ & excellent & adult \\
\hline Kuether et al., 1998 & 1 & uro & $250,000-U$ bolus, $60,000-100,000 \mathrm{U} / \mathrm{hr} \times 48 \mathrm{hrs}$ & neuro improve & adult \\
\hline Niwa et al., 1998 & 1 & tPA & $3,200,000 \mathrm{U}$ & excellent & adult \\
\hline
\end{tabular}

(continued) 


\section{Endovascular treatment for CVST}

TABLE 1: Direct thrombolysis for CVST*(continued)

\begin{tabular}{|c|c|c|c|c|c|}
\hline Authors \& Year & $\begin{array}{l}\text { No. of } \\
\text { Cases }\end{array}$ & Agent & Dose & Outcome & Age \\
\hline Ekseth et al., 1998 & 3 & $\mathrm{tPA}$ & $8 \mathrm{mg} / 4 \mathrm{hrs}$ (repeated in 2) & excellent (2), neuro improve (1) & adult \\
\hline Frey et al., 1999 & 12 & tPA & $23-128 \mathrm{mg} \times 13-77 \mathrm{hrs}$ & $\begin{array}{l}\text { immediate recovery }(7), \text { long- } \\
\text { term partial recovery (5) }\end{array}$ & adult \\
\hline Philips et al., 1999 & 4 & uro & $200,000-1,000,000 \mathrm{U}$ & all pts improved & both \\
\hline Witham et al., 1999 & 1 & uro & $1,900,000 \mathrm{U}$ & excellent & adult \\
\hline Manzione et al., 2000 & 1 & uro & $400,000-\mathrm{U}$ bolus, $120,000 \mathrm{U} / \mathrm{hr} \times 3$ days & excellent & adult \\
\hline Ra et al., 2001 & 1 & uro & $900,000 \mathrm{U}$ & excellent & adult \\
\hline Wasay et al., 2001 & 20 & uro & $250,000-\mathrm{U}$ bolus, $80,000 \mathrm{U} / \mathrm{hr} \times 16-84 \mathrm{hrs}$ & $\begin{array}{l}\text { normal (16), neuro deficit: mild } \\
\quad \text { (3), } \bmod (1)\end{array}$ & both \\
\hline Yamini et al., 2001 & 1 & tPA & 25 -mg bolus, $1 \mathrm{mg} / \mathrm{min} \times 19 \mathrm{hrs}$ & complete neuro recovery & adult \\
\hline $\begin{array}{l}\text { Del-Rio Camacho et } \\
\text { al., } 2001\end{array}$ & 1 & tPA & $0.2-\mathrm{mg} / \mathrm{kg}$ bolus, $0.5 \mathrm{mg} / \mathrm{kg} / \mathrm{hr} \times 3 \mathrm{hrs}$ & excellent & ped \\
\hline Buccino et al., 2001 & 2 & uro & $150,000-200,000$ U bolus, $50,000-60,000 \mathrm{U} / 24 \mathrm{hrs}$ & good & adult \\
\hline $\begin{array}{l}\text { Dzialo \& Black-Schaf- } \\
\quad \text { fer, } 2001\end{array}$ & 1 & uro & $4,000,000 \mathrm{U} / 96 \mathrm{hrs}$ & excellent & adult \\
\hline Gebara \& Everett, 2001 & 1 & uro & $125,000 \mathrm{U} / 80 \mathrm{~min}$ & excellent & ped \\
\hline Kollar et al., 2001 & 1 & uro & $\begin{array}{l}\text { 1st tx: } 1,200,000-U \text { bolus; } 2 \text { nd tx: } 1,400,000-U \\
\text { bolus, } 50,000 \mathrm{U} / \mathrm{hr} \times 24 \mathrm{hrs}, 25,000 \mathrm{U} / \mathrm{hr} \times 72 \mathrm{hrs}\end{array}$ & excellent & adult \\
\hline Huh et al., 2002 & 1 & uro & $1,500,000-\mathrm{U}$ bolus, $1,500,000 \mathrm{U} / 2 \mathrm{hrs}$ & neuro improve & adult \\
\hline Kao et al., 2002 & 1 & uro & NR & neuro improve & ped \\
\hline Ming et al., 2002 & 5 & uro & $200,000 \mathrm{U} / 15 \mathrm{~min}$ & excellent & adult \\
\hline Soleau et al., 2003 & 10 & $\begin{array}{l}\text { uro } \\
(8) / \\
\text { tPA } \\
(2)\end{array}$ & NR & $\begin{array}{l}\text { clinical improve (6), deterior } \\
\text { (1), dead (3) (hemorrhagic } \\
\text { complications causing } 3 / 4 \\
\text { poor outcomes) }\end{array}$ & adult \\
\hline Weatherby et al., 2003 & 1 & tPA & 48 mg (2 separate tx) & excellent & $\begin{array}{l}\text { adult (preg- } \\
\text { nant) }\end{array}$ \\
\hline Zerah et al., 2007 & 1 & tPA & $55-\mathrm{mg}$ bolus, $3 \mathrm{mg} / \mathrm{hr} \times 24 \mathrm{hrs}$ & excellent & ped \\
\hline Hocker et al., 2008 & 1 & tPA & $70 \mathrm{mg}$ & excellent & adult \\
\hline Sidani et al., 2008 & 1 & tPA & NR & neuro improve & adult \\
\hline Stam et al., 2008 & 20 & uro & $120,000-600,000-U$ bolus, $100,000 \mathrm{U} / \mathrm{hr} \times 24 \mathrm{hrs}$ & $\begin{array}{l}\text { clinical recovery (12), handi- } \\
\text { capped (2), dead (6) }\end{array}$ & both \\
\hline Sujith et al., 2008 & 3 & uro & $3,000,000-3,600,000 / 24-48 \mathrm{hrs}$ & neuro improve & adult \\
\hline
\end{tabular}

* AVF = arteriovenous fistula; deterior = deterioration; FU = follow-up; improve = improvement; mod = moderate; neuro = neurological; NR = not reported; ped $=$ pediatric; strepto = streptokinase; uro = urokinase .

series. ${ }^{89}$ Risk factors for CVST are similar to risk factors for all venous thrombotic disorders and include oral contraceptive or hormone therapy, steroids, infection, malignancy, trauma, pregnancy, underlying hematological disorder, vasculitis, and mechanical precipitants (for example, lumbar puncture and neurosurgery). ${ }^{16,17,77}$ Although almost $25 \%$ of cases will have no clear cause even after an extensive workup, ${ }^{2}$ CVST is extremely variable in its clinical presentation. Headache is the most common clinical symptom, occurring in $75-95 \%$ of all cases. ${ }^{2,16,21}$ Other symptoms and signs include visual loss, papilledema, diplopia, stupor, motor deficits, seizures, coma, and death. ${ }^{21,34}$ Diagnosis is confirmed by angiography, CT venography, and/or MR imaging. ${ }^{58}$ 
TABLE 2: Mechanical thrombolysis/thrombectomy for CVST*

\begin{tabular}{|c|c|c|c|c|c|c|}
\hline Authors \& Year & $\begin{array}{l}\text { No. of } \\
\text { Cases }\end{array}$ & Agent & Dose & Device & Outcome & Age \\
\hline Gurley et al., 1996 & 2 & uro & $\begin{array}{l}250,000 \text { bolus, } 4000 \mathrm{U} / \mathrm{min} \times 2 \\
\text { hrs, } 2000 \mathrm{U} / \mathrm{min} \times 2 \mathrm{hrs}\end{array}$ & balloon angio (1) & clinical improve & adult \\
\hline Dowd et al., 1999 & 1 & uro & $\begin{array}{l}750,000-U \text { bolus, } 3,000,000 \\
\text { U/48 hrs }\end{array}$ & rheolytic catheter & significant neuro recovery & adult \\
\hline Malek et al., 1999 & 1 & NR & NR & balloon angio/stent & neurologically normal & ped \\
\hline Chaloupka et al., 1999 & 1 & uro & $750,000 \mathrm{U}$ & balloon angio & excellent & adult \\
\hline Philips et al., 1999 & 2 & uro & $200,000-1,000,000 \mathrm{U}$ & $\begin{array}{l}\text { thrombectomy w/ wire } \\
\text { microsnare }\end{array}$ & all improved & both \\
\hline Gomez et al., 2000 & 1 & uro & $375,000-U$ bolus & rheolytic catheter & excellent & adult \\
\hline Opatowsky et al., 1999 & 1 & uro & $450,000-750,000 \mathrm{U}$ & rheolytic catheter & excellent & adult \\
\hline Chow et al., 2000 & 2 & $\begin{array}{l}\text { uro (intra- } \\
\text { arterial \& } \\
\text { directly in } \\
\text { sinus) }\end{array}$ & $\begin{array}{l}100,000 \mathrm{U} / \mathrm{hr} \times 4 \mathrm{hrs} \text { (arte- } \\
\quad \text { rial only), } 400,000 \mathrm{U} \text { in } 4 \mathrm{hrs} \\
\quad \text { (intraarterial \& sinus) }\end{array}$ & rheolytic catheter & $\begin{array}{l}\text { excellent (1), neuro } \\
\text { recovery (1) }\end{array}$ & adult \\
\hline Novak et al., 2000 & 1 & uro & $\begin{array}{l}\text { bolus, } 125,000 \mathrm{U} / \mathrm{hr} \\
\quad \times 4 \mathrm{hrs}\end{array}$ & balloon angio & excellent & adult \\
\hline Baker et al., 2001 & 5 & uro & NR & $\begin{array}{l}\text { rheolytic catheter (all), } \\
\text { balloon angio (3) }\end{array}$ & $\begin{array}{l}\text { excellent/good (4), severe } \\
\text { neuro deficits (1) }\end{array}$ & adult \\
\hline Hunt et al., 2001 & 2 & uro (1) & NR & balloon angio/stent & excellent & both \\
\hline Kollar et al., 2001 & 1 & uro & $\begin{array}{l}100,000-1,200,000-U \text { bolus, } \\
\text { then } 10,000-50,000-U \text { infu- } \\
\text { sion } / \mathrm{hr} \times 12 \mathrm{hrs}\end{array}$ & balloon angio & good & adult \\
\hline Chaves et al., 2002 & 1 & $\mathrm{tPA}$ & $10-48 \mathrm{mg} \times$ mult tx/10 days & rheolytic catheter & neuro improve & adult \\
\hline Chahlavi et al., 2004 & 2 & uro & & rheolytic catheter & neuro improve & adult \\
\hline Curtin et al., 2004 & 1 & tPA & $\begin{array}{c}0.3 \mathrm{mg} / \mathrm{hr} \times 15 \mathrm{hrs}(1 \mathrm{st} \mathrm{tx}), 0.45 \\
\mathrm{mg} / \mathrm{hr} \times 22 \mathrm{hrs}(2 \mathrm{nd} \mathrm{tx})\end{array}$ & rheolytic catheter $\times 2$ tx & excellent & adult \\
\hline Prasad et al., 2006 & 1 & tPA & $2.75 \mathrm{mg}$ & balloon angio & excellent & ped \\
\hline Zhang et al., 2008 & 6 & tPA & $5-15 \mathrm{mg}$ & rheolytic catheter & excellent/good (4), dead (2) & adult \\
\hline Bishop et al., 2009 & 1 & heparin & $500 \mathrm{U} / \mathrm{hr} \times 3$ days & balloon angio & neuro improve & ped \\
\hline Newman et al., 2009 & 1 & retaplase & $1.5-2-\mathrm{U}$ bolus & Merci clot retrieval device & excellent & adult \\
\hline Summers, 2009 & 1 & tPA & $8 \mathrm{mg}$ & thrombectomy & neuro improve & adult \\
\hline
\end{tabular}

* angio = angioplasty; mult $=$ multiple.

The diagnosis of CVST continues to be elusive given the wide spectrum of clinical signs and symptoms, subacute to chronic onset, imaging appearance, and outcome. However, given the possibility for serious morbidity and mortality, timely treatment is critical. First-line treatment is systemic anticoagulation with studies demonstrating improved neurological outcomes in patients who received systemic heparin compared with controls. ${ }^{22,28,40}$ Heparin has also been found to be safe in the treatment of CVST in the setting of $\mathrm{ICH} .{ }^{22,28}$ After the acute period, patients are usually switched to oral anticoagulation for 3-12 months depending on the cause of CVST. ${ }^{33,62}$ Additionally, patients may require concomitant treatment for CVST complications including seizures and intracranial hypertension. However, even with these measures, some patients continue to decline or fail to improve. These cases have been shown to benefit from thrombolysis and thrombec- tomy. Most reports of the use of thrombolysis for CVST have described direct infusion with a microcatheter, although some cases were treated with systemic delivery. In a systemic review published in 2003 comparing 118 patients who were treated with local thrombolysis with 15 patients treated with systemic thrombolysis, the groups did not differ in terms of the rates of death, dependency, hemorrhages, or other complications. ${ }^{11}$ However, the systemic thrombolysis group was more likely to have only partial or no recanalization (OR 8.9, 95\% CI 2.4-33.8).

\section{Direct Thrombolysis}

Systemic thrombolysis in the treatment of CVST was first described by Vines and Davis ${ }^{91}$ in 1971 with intravenous infusion of urokinase in 5 patients. Since the development of endovascular access to cerebrovascular disease, 


\section{Endovascular treatment for CVST}

most reports of thrombolysis in the treatment of CVST involve direct infusion of thrombolytics. In the English-language literature, 70 publications have described direct infusion of various thrombolytics in the treatment of CVST. The early reports consist of case reports or small series that used urokinase in adults or children. These reports demonstrated excellent to good outcomes in 140 of 161 patients, even if direct thrombolysis was performed after prolonged treatment with systemic anticoagulation (up to 3 months). ${ }^{82}$ Additionally, thrombolytic infusion was found to be safe in the setting of preexisting $\mathrm{ICH},{ }^{47}$ similar to treatment with systemic anticoagulation. ${ }^{22,28}$ Most of the publications described a transfemoral approach, although some clinicians accessed the venous sinuses via a fontanelle puncture, bur holes, or craniotomy. ${ }^{3,29,44,56,70,78}$ The dose of urokinase varied. Many regimens involved a bolus at the time of the intervention, followed by a continuous infusion by leaving the catheter in place. $8,47,78,82$ These patients underwent frequent venography to assess the status of the thrombosis. Other authors have described only a bolus ${ }^{90}$ or a continuous infusion. ${ }^{7,44}$

Two reports described treatment with streptokinase $^{52,70}$ and 15 described treatment with tPA. . $^{3,19,23,35,45,67 \text {, }}$ 72,75,79,83,87,93,95-97 Most of these patients received systemic and/or intrasinus heparin in addition to direct thrombolysis with thrombolytic therapy. Wasay et al. ${ }^{92}$ conducted a retrospective study to compare the efficacy of systemic heparin with that of direct chemical thrombolysis. The heparin group (20 patients) and thrombolysis group (20 patients) were at 2 different institutions, and the thrombolysis group did not receive heparin. The neurological function was worse in thrombolysis group before treatment, but it was better than the heparin group at the time of discharge $(p=0.019)$. Hemorrhagic complications were observed in 10\% (2 patients) of the thrombolysis group compared with $0 \%$ of the heparin group. These results were promising for thrombolysis alone. However, further prospective trials have not been conducted, and most institutions continue to combine direct thrombolysis with systemic anticoagulation. Moreover, with the advent of sophisticated endovascular techniques, many have combined chemical thrombolysis and systemic anticoagulation with mechanical thrombectomy.

\section{Mechanical Thrombolysis/Thrombectomy}

Twenty publications have described mechanical thrombolysis/thrombectomy in 34 patients. All but 3 of these studies used mechanical techniques in combination with thrombolytics. ${ }^{12,49,59}$ Two patients underwent craniotomy and direct dural sinus access of the catheter for endovascular thrombectomy. ${ }^{12}$ Generally, the thrombolytics were given as a bolus during the procedure and in some cases, followed by continuous infusion. Many of the publications reported balloon angioplasty or use of a rheolytic catheter to break up the clot. 5,9,12,13,15,19,25,43,68,72,97 Two reports described balloon angioplasty with stent placement. ${ }^{49,59}$ In 1 case, the patient initially underwent balloon angioplasty alone. ${ }^{59}$ However, after initial improvement, the 13 -year-old patient experienced worsening episodes of aphasia and underwent angiography, which revealed reocclusion. He subsequently underwent further balloon angioplasty and stent placement in his occipital sinus. He was discharged home on a regimen of warfarin, ticlopidine, and aspirin, and he did not suffer any neurological deficits. The second report involved 2 patients who underwent balloon angioplasty of the transverse sinus with significant improvement in sinus venous pressure and the patients' vision. ${ }^{49}$

The only prospective study of CVST endovascular treatment enrolled 20 patients with a mean age of 32 years. ${ }^{85}$ Patients were selected for endovascular intervention if they had an altered mental status, straight sinus thrombosis, or large mass lesion. The study patients were mostly critically ill prior to treatment; 12 of the patients were comatose, 14 had hemorrhagic infarcts, and 11 had deep cerebral thrombosis. Fifteen patients underwent urokinase thrombolysis with thrombosuction using a rheolytic catheter, 4 underwent thrombolysis only, and 1 patient did not undergo any intervention because of difficulty in accessing the sinus. Nine patients recovered or had minimal symptoms, 3 had a minor handicap, and 2 had a moderate or severe handicap as measured using the Rankin scale. The 6 patients who died were more likely to have leukemia (3 of 6) and or large hemorrhagic infarcts (4 of 6). Five patients had increased cerebral hemorrhage ( 3 minor and 2 major) after endovascular treatment, and 4 of these patients died. Although the authors noted that they believed that only 1 of these patients died of increase in ICH size, the other 4 patients were in critical condition prior to intervention. ${ }^{85}$ This study demonstrated the significant morbidity and mortality that can be associated with CVST. Due to selection of a severely compromised patient population, the outcomes in this study were much worse than those in previous reports. However, despite the severe nature of the enrolled patients' CVSTs, many of the patients experienced a remarkable recovery, with 12 achieving almost complete recovery.

A large portion of the patients in the literature who were treated with thrombolytics were encephalopathic or comatose at the time of treatment, but they had excellent outcomes. Although promising, the results of direct thrombolysis and thrombectomy must be interpreted cautiously. The studies are mostly case reports, without standard reporting of treatment and outcome measures. Other therapy such as barbiturate coma or craniectomy may have also benefited the patients. Additionally, publication bias has most likely selected for publications with good outcomes. The authors of a review published in the Cochrane Database in 2004 concluded that the current evidence could not support the routine use of thrombolytics in the treatment of CVST. They discouraged further publications of case reports of this treatment and encouraged an RCT. An RCT analyzing vessel patency and/or complications after direct thrombolysis/thrombectomy would be useful in validating this treatment for CVST. On the other hand, an RCT measuring clinical efficacy would require a large sample size and multicenter collaboration, making it a more formidable undertaking. Based on our interpretation of the current literature, we have devised a treatment algorithm for our patients (Fig. 1). Patients who present with severe neurological deficits (GCS score $\leq 8$ ) are strongly considered for direct thrombolysis/thrombectomy immediately. Patients with GCS scores between 9 and 12 may be considered for immediate endovascular treatment. For other patients (GCS 


\section{Rahman et al.}

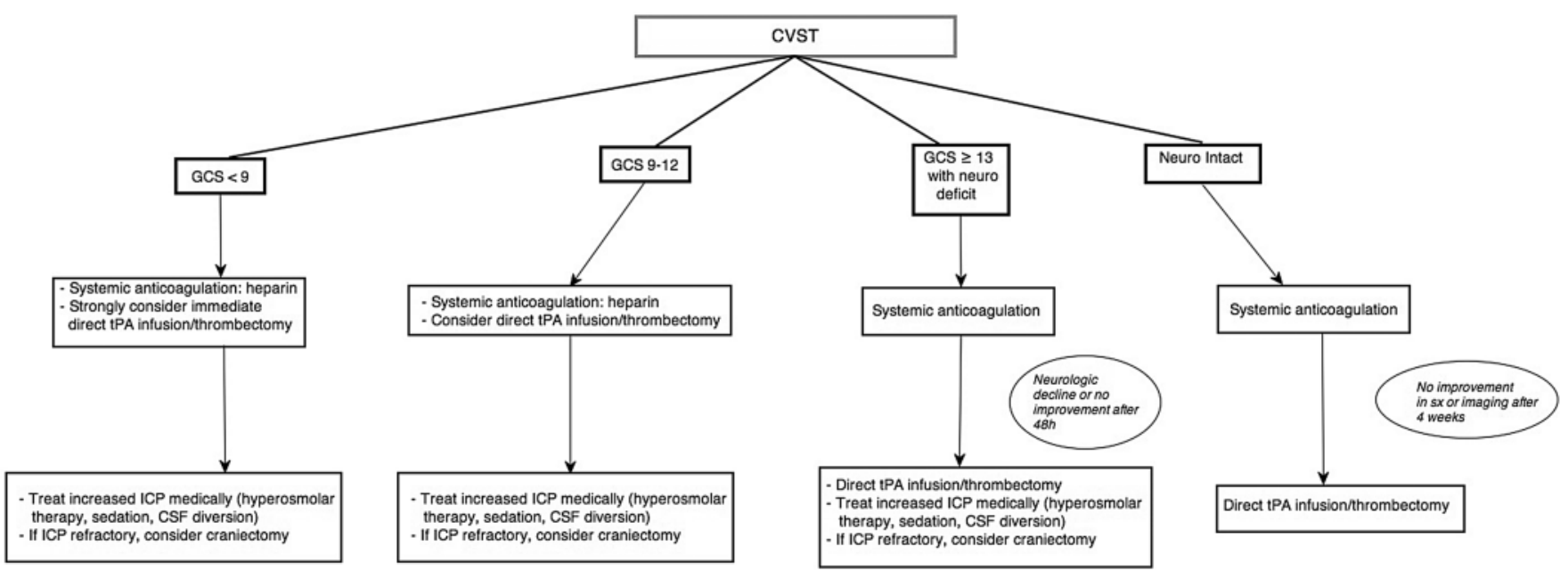

FIG. 1. Flow chart for the treatment of CVST.

score $>12$ ), direct thrombolysis/thrombectomy would be considered only after a trial of systemic anticoagulation. Although useful, this algorithm can only be validated with a properly designed prospective study.

\section{Conclusions}

Cerebral venous sinus thrombosis is an increasingly recognized cause of neurological illness with a range of clinical symptoms. Standard treatment is systemic anticoagulation. However, in a subset of patients who decline despite adequate treatment or have a dramatic initial presentation, direct thrombolysis/thrombectomy may be performed. Small case series and prospective studies have demonstrated safety and good initial results with direct thrombolytic infusions, mechanical thrombectomy, and stenting. Well-designed prospective studies are necessary to further investigate endovascular treatment as standard of care for patients with CVST.

\section{Disclosure}

Dr. Hoh is a consultant for Micrus Endovascular and Codman Neurovascular. The authors report no other conflicts of interest concerning the materials or methods used in this study or the findings specified in this paper.

\section{References}

1. Akai T, Kuwayama N, Ogiichi T, Kurimoto M, Endo S, Takaku A: Leptomeningeal melanoma associated with straight sinus thrombosis - case report. Neurol Med Chir (Tokyo) 37:757761,1997

2. Ameri A, Bousser MG: Cerebral venous thrombosis. Neurol Clin 10:87-111, 1992

3. Aoki N, Uchinuno H, Tanikawa T, Kagawa M, Takakura K: Superior sagittal sinus thrombosis treated with combined local thrombolytic and systemic anticoagulation therapy. Acta Neurochir (Wien) 139:332-335, 1997

4. Averback P: Primary cerebral venous thrombosis in young adults: the diverse manifestations of an underrecognized disease. Ann Neurol 3:81-86, 1978

5. Baker MD, Opatowsky MJ, Wilson JA, Glazier SS, Morris PP: Rheolytic catheter and thrombolysis of dural venous sinus thrombosis: a case series. Neurosurgery 48:487-494, 2001
6. Barnett HJ, Hyland HH: Noninfective intracranial venous thrombosis. Brain 76:36-49, 1953

7. Barnwell SL, Higashida RT, Halbach VV, Dowd CF, Hieshima GB: Direct endovascular thrombolytic therapy for dural sinus thrombosis. Neurosurgery 28:135-142, 1991

8. Barnwell SL, Nesbit GM, Clark WM: Local thrombolytic therapy for cerebrovascular disease: current Oregon Health Sciences University experience (July 1991 through April 1995). J Vasc Interv Radiol 6:78S-82S, 1995

9. Bishop FS, Finn MA, Samuelson M, Schmidt RH: Endovascular balloon angioplasty for treatment of posttraumatic venous sinus thrombosis. Case report. J Neurosurg 111:17-21, 2009

10. Buccino G, Scoditti U, Pini M, Menozzi R, Piazza P, Zuccoli $\mathrm{P}$, et al: Loco-regional thrombolysis in the treatment of cerebral venous and sinus thrombosis: report of two cases. Acta Neurol Scand 103:59-63, 2001

11. Canhao P, Falcao F, Ferro JM: Thrombolytics for cerebral sinus thrombosis: a systematic review. Cerebrovasc Dis 15:159166,2003

12. Chahlavi A, Steinmetz MP, Masaryk TJ, Rasmussen PA: A transcranial approach for direct mechanical thrombectomy of dural sinus thrombosis. Report of two cases. J Neurosurg 101:347-351, 2004

13. Chaloupka JC, Mangla S, Huddle DC: Use of mechanical thrombolysis via microballoon percutaneous transluminal angioplasty for the treatment of acute dural sinus thrombosis: case presentation and technical report. Neurosurgery 45:650-657, 1999

14. Chaves C, Voetsch B, Loscalzo J, Caplan L, Chavali R: Extensive cerebral venous thrombosis associated with moderate hyperhomocyst(e)inemia and successfully treated with thrombolysis. Cerebrovasc Dis 13:214-216, 2002

15. Chow K, Gobin YP, Saver J, Kidwell C, Dong P, Vinuela F: Endovascular treatment of dural sinus thrombosis with rheolytic thrombectomy and intra-arterial thrombolysis. Stroke 31:1420-1425, 2000

16. Ciccone A, Canhão P, Falcão F, Ferro JM, Sterzi R: Thrombolysis for cerebral vein and dural sinus thrombosis. Cochrane Database Syst Rev:CD003693, 2004

17. Coutinho JM, Ferro JM, Canhão P, Barinagarrementeria F, Cantú C, Bousser MG, et al: Cerebral venous and sinus thrombosis in women. Stroke 40:2356-2361, 2009

18. Cumurciuc R, Crassard I, Sarov M, Valade D, Bousser MG: Headache as the only neurological sign of cerebral venous thrombosis: a series of 17 cases. J Neurol Neurosurg Psychiatry 76:1084-1087, 2005 


\section{Endovascular treatment for CVST}

19. Curtin KR, Shaibani A, Resnick SA, Russell EJ, Simuni T: Rheolytic catheter thrombectomy, balloon angioplasty, and direct recombinant tissue plasminogen activator thrombolysis of dural sinus thrombosis with preexisting hemorrhagic infarctions. AJNR Am J Neuroradiol 25:1807-1811, 2004

20. D'Alise MD, Fichtel F, Horowitz M: Sagittal sinus thrombosis following minor head injury treated with continuous urokinase infusion. Surg Neurol 49:430-435, 1998

21. de Bruijn SF, de Haan RJ, Stam J: Clinical features and prognostic factors of cerebral venous sinus thrombosis in a prospective series of 59 patients. For The Cerebral Venous Sinus Thrombosis Study Group. J Neurol Neurosurg Psychiatry 70:105-108, 2001

22. de Bruijn SF, Stam J: Randomized, placebo-controlled trial of anticoagulant treatment with low-molecular-weight heparin for cerebral sinus thrombosis. Stroke 30:484-488, 1999

23. Del-Rio Camacho G, Orozco AL, Perez-Higueras A, Camino Lopez M, Al-Assir I, Ruiz-Moreno M: Moyamoya disease and sagittal sinus thrombosis in a child with Down's syndrome. Pediatr Radiol 31:125-128, 2001

24. Di Rocco C, Iannelli A, Leone G, Moschini M, Valori VM: Heparin-urokinase treatment in aseptic dural sinus thrombosis. Arch Neurol 38:431-435, 1981

25. Dowd CF, Malek AM, Phatouros CC, Hemphill JC: Application of a rheolytic thrombectomy device in the treatment of dural sinus thrombosis: a new technique. AJNR Am J Neuroradiol 20:568-570, 1999

26. Dzialo AF, Black-Schaffer RM: Cerebral venous thrombosis in young adults: 2 case reports. Arch Phys Med Rehabil 82:683-688, 2001

27. Ehlers H, Courville CB: Thrombosis of internal veins in infancy and childhood: review of literature and reports of five cases. J Pediatr 8:600-623, 1936

28. Einhaupl KM, Villringer A, Meister W, Mehraein S, Garner C, Pellkofer M, et al: Heparin treatment in sinus venous thrombosis. Lancet 338:597-600, 1991

29. Ekseth K, Bostrom S, Vegfors M: Reversibility of severe sagittal sinus thrombosis with open surgical thrombectomy combined with local infusion of tissue plasminogen activator: technical case report. Neurosurgery 43:960-965, 1998

30. Eskridge JM, Wessbecher FW: Thrombolysis for superior sagittal sinus thrombosis. J Vasc Interv Radiol 2:89-94, 1991

31. Evans MS, Naritoku DK, Couch JR, Ghobrial MW: Onset of neurologic deficits after treatment with dihydroergotamine in a patient with sagittal sinus thrombosis. Clin Neuropharmacol 19:177-184, 1996

32. Ferro JM: [Cerebral venous thrombosis.] J Neuroradiol 29: 231-239, $2002(\mathrm{Fr})$

33. Ferro JM, Canhao P: Acute treatment of cerebral venous and dural sinus thrombosis. Curr Treat Options Neurol 10:126137,2008

34. Ferro JM, Canhao P, Stam J, Bousser MG, Barinagarrementeria F: Prognosis of cerebral vein and dural sinus thrombosis: results of the International Study on Cerebral Vein and Dural Sinus Thrombosis (ISCVT). Stroke 35:664-670, 2004

35. Frey JL, Muro GJ, McDougall CG, Dean BL, Jahnke HK: Cerebral venous thrombosis: combined intrathrombus rtPA and intravenous heparin. Stroke 30:489-494, 1999

36. Funabiki Y, Fujii H, Fujitake J, Takasu K, Nishimura K, Hayakawa K, et al: Four cases of cerebral venous sinus thrombosis. Eur Neurol 48:228-230, 2002

37. Gebara BM, Everett KO: Dural sinus thrombosis complicating hypernatremic dehydration in a breastfed neonate. Clin Pediatr (Phila) 40:45-48, 2001

38. Gebara BM, Goetting MG, Wang AM: Dural sinus thrombosis complicating subclavian vein catheterization: treatment with local thrombolysis. Pediatrics 95:138-140, 1995

39. Gerszten PC, Welch WC, Spearman MP, Jungreis CA, Redner RL: Isolated deep cerebral venous thrombosis treated by direct endovascular thrombolysis. Surg Neurol 48:261-266, 1997

40. Girot M, Ferro JM, Canhao P, Stam J, Bousser MG, Barinagarrementeria F, et al: Predictors of outcome in patients with cerebral venous thrombosis and intracerebral hemorrhage. Stroke 38:337-342, 2007

41. Gomez CR, Misra VK, Terry JB, Tulyapronchote R, Campbell MS: Emergency endovascular treatment of cerebral sinus thrombosis with a rheolytic catheter device. J Neuroimaging 10:177-180, 2000

42. Griesemer DA, Theodorou AA, Berg RA, Spera TD: Local fibrinolysis in cerebral venous thrombosis. Pediatr Neurol 10:78-80, 1994

43. Gurley MB, King TS, Tsai FY: Sigmoid sinus thrombosis associated with internal jugular venous occlusion: direct thrombolytic treatment. J Endovasc Surg 3:306-314, 1996

44. Higashida RT, Helmer E, Halbach VV, Hieshima GB: Direct thrombolytic therapy for superior sagittal sinus thrombosis. AJNR Am J Neuroradiol 10:S4-S6, 1989

45. Hocker SE, Dafer RM, Hacein-Bey L: Successful delayed thrombolysis for cerebral venous and dural sinus thrombosis: a case report and review of the literature. J Stroke Cerebrovasc Dis 17:429-432, 2008

46. Holder CA, Bell DA, Lundell AL, Ulmer JL, Glazier SS: Isolated straight sinus and deep cerebral venous thrombosis: successful treatment with local infusion of urokinase. Case report. J Neurosurg 86:704-707, 1997

47. Horowitz M, Purdy P, Unwin H, Carstens G III, Greenlee R, Hise J, et al: Treatment of dural sinus thrombosis using selective catheterization and urokinase. Ann Neurol 38:58-67, 1995

48. Huh PW, Cho KS, Yoo DS, Kim JK, Kim DS, Kang JK: Deep cerebral venous thrombosis. Acta Neurochir (Wien) 144:103105,2002

49. Hunt MG, Lee AG, Kardon RH, Lesley WS, Chaloupka JC: Improvement in papilledema and visual loss after endovascular stent placement in dural sinus thrombosis. Neuroophthalmology 26:85-92, 2001

50. Kao A, Dlugos D, Hunter JV, Mamula P, Thorarensen O: Anticoagulation therapy in cerebral sinovenous thrombosis and ulcerative colitis in children. J Child Neurol 17:479-482, 2002

51. Kasner SE, Gurian JH, Grotta JC: Urokinase treatment of sagittal sinus thrombosis with venous hemorrhagic infarction. J Stroke Cerebrovasc Dis 7:421-425, 1998

52. Kermode AG, Ives FJ, Taylor B, Davis SJ, Carroll WM: Progressive dural venous sinus thrombosis treated with local streptokinase infusion. J Neurol Neurosurg Psychiatry 58:107-108, 1995

53. Khoo KB, Long FL, Tuck RR, Allen RJ, Tymms KE: Cerebral venous sinus thrombosis associated with the primary antiphospholipid syndrome. Resolution with local thrombolytic therapy. Med J Aust 162:30-32, 1995

54. Kim SY, Suh JH: Direct endovascular thrombolytic therapy for dural sinus thrombosis: infusion of alteplase. AJNR Am J Neuroradiol 18:639-645, 1997

55. Kollar C, Parker G, Johnston I: Endovascular treatment of cranial venous sinus obstruction resulting in pseudotumor syndrome. Report of three cases. J Neurosurg 94:646-651, 2001

56. Kourtopoulos H, Christie M, Rath B: Open thrombectomy combined with thrombolysis in massive intracranial sinus thrombosis. Acta Neurochir (Wien) 128:171-173, 1994

57. Kuether TA, O'Neill O, Nesbit GM, Barnwell SL: Endovascular treatment of traumatic dural sinus thrombosis: case report. Neurosurgery 42:1163-1167, 1998

58. Linn J, Pfefferkorn T, Ivanicova K, Müller-Schunk S, Hartz S, Wiesmann M, et al: Noncontrast CT in deep cerebral venous thrombosis and sinus thrombosis: comparison of its diagnostic value for both entities. AJNR Am J Neuroradiol 30: 728-735, 2009 


\section{Rahman et al.}

59. Malek AM, Higashida RT, Balousek PA, Phatouros CC, Smith WS, Dowd CF, et al: Endovascular recanalization with balloon angioplasty and stenting of an occluded occipital sinus for treatment of intracranial venous hypertension: technical case report. Neurosurgery 44:896-901, 1999

60. Manthous CA, Chen H: Case report: treatment of superior sagittal sinus thrombosis with urokinase. Conn Med 56:529530,1992

61. Manzione J, Newman GC, Shapiro A, Santo-Ocampo R: Diffusion- and perfusion-weighted MR imaging of dural sinus thrombosis. AJNR Am J Neuroradiol 21:68-73, 2000

62. Masuhr F, Einhaupl K: Treatment of cerebral venous and sinus thrombosis. Front Neurol Neurosci 23:132-143, 2008

63. Masuhr F, Mehraein S, Einhaupl K: Cerebral venous and sinus thrombosis. J Neurol 251:11-23, 2004

64. Ming S, Qi Z, Wang L, Zhu K: Deep cerebral venous thrombosis in adults. Chin Med J (Engl) 115:395-397, 2002

65. Nagatomo Y, Yanaka K, Kamezaki T, Kobayashi E, Matsumura A, Nose T: Recovery from primary deep cerebral venous sinus thrombosis with recanalisation. Neuroradiology 37: 645-648, 1995

66. Newman CB, Pakbaz R, Nguyen A, Kerber C: Endovascular treatment of extensive cerebral sinus thrombosis. J Neurosurg 110:442-445, 2009

67. Niwa J, Ohyama H, Matumura S, Maeda Y, Shimizu T: Treatment of acute superior sagittal sinus thrombosis by t-PA infusion via venography - direct thrombolytic therapy in the acute phase. Surg Neurol 49:425-429, 1998

68. Novak Z, Coldwell DM, Brega KE: Selective infusion of urokinase and thrombectomy in the treatment of acute cerebral sinus thrombosis. AJNR Am J Neuroradiol 21:143-145, 2000

69. Opatowsky MJ, Morris PP, Regan JD, Mewborne JD, Wilson JA: Rapid thrombectomy of superior sagittal sinus and transverse sinus thrombosis with a rheolytic catheter device. AJNR Am J Neuroradiol 20:414-417, 1999

70. Persson L, Lilja A: Extensive dural sinus thrombosis treated by surgical removal and local streptokinase infusion. Neurosurgery 26:117-121, 1990

71. Philips MF, Bagley LJ, Sinson GP, Raps EC, Galetta SL, Zager EL, et al: Endovascular thrombolysis for symptomatic cerebral venous thrombosis. J Neurosurg 90:65-71, 1999

72. Prasad RS, Michaels LA, Roychowdhury S, Craig V, Sorrell A, Schonfeld S: Combined venous sinus angioplasty and low-dose thrombolytic therapy for treatment of hemorrhagic transverse sinus thrombosis in a pediatric patient. J Pediatr Hematol Oncol 28:196-199, 2006

73. Ra CS, Lui CC, Liang CL, Chen HJ, Kuo YL, Chen WF: Superior sagittal sinus thrombosis induced by thyrotoxicosis. Case report. J Neurosurg 94:130-132, 2001

74. Rael JR, Orrison WW Jr, Baldwin N, Sell J: Direct thrombolysis of superior sagittal sinus thrombosis with coexisting intracranial hemorrhage. AJNR Am J Neuroradiol 18:12381242,1997

75. Renowden SA, Oxbury J, Molyneux AJ: Case report: venous sinus thrombosis: the use of thrombolysis. Clin Radiol 52: 396-399, 1997

76. Rondepierre P, Hamon M, Leys D, Leclerc X, Mounier-Vehier F, Godefroy O, et al: [Cerebral venous thromboses: study of the course.] Rev Neurol (Paris) 151:100-104, 1995 (Fr)

77. Saadatnia M, Fatehi F, Basiri K, Mousavi SA, Mehr GK: Cerebral venous sinus thrombosis risk factors. Int J Stroke 4: 111-123, 2009

78. Scott JA, Pascuzzi RM, Hall PV, Becker GJ: Treatment of dural sinus thrombosis with local urokinase infusion. Case report. J Neurosurg 68:284-287, 1988

79. Sidani CA, Ballourah W, El Dassouki M, Muwakkit S, Dabbous I, Dahoui H, et al: Venous sinus thrombosis leading to stroke in a patient with sickle cell disease on hydroxyurea and high hemoglobin levels: treatment with thrombolysis. Am J Hematol 83:818-820, 2008
80. Sindou M, Mercier P, Bokor J, Brunon J: Bilateral thrombosis of the transverse sinuses: microsurgical revascularization with venous bypass. Surg Neurol 13:215-220, 1980

81. Smith AG, Cornblath WT, Deveikis JP: Local thrombolytic therapy in deep cerebral venous thrombosis. Neurology 48:1613-1619, 1997

82. Smith TP, Higashida RT, Barnwell SL, Halbach VV, Dowd $\mathrm{CF}$, Fraser KW, et al: Treatment of dural sinus thrombosis by urokinase infusion. AJNR Am J Neuroradiol 15:801-807, 1994

83. Soleau SW, Schmidt R, Stevens S, Osborn A, Macdonald J: Extensive experience with dural sinus thrombosis. Neurosurgery 52:534-544, 2003

84. Spearman MP, Jungreis CA, Wehner JJ, Gerszten PC, Welch WC: Endovascular thrombolysis in deep cerebral venous thrombosis. AJNR Am J Neuroradiol 18:502-506, 1997

85. Stam J, Majoie CB, van Delden OM, van Lienden KP, Reekers JA: Endovascular thrombectomy and thrombolysis for severe cerebral sinus thrombosis: a prospective study. Stroke 39:1487-1490, 2008

86. Sujith OK, Krishnan R, Asraf V, Rahman A, Girija AS: Local thrombolysis in patients with dural venous thrombosis unresponsive to heparin. J Stroke Cerebrovasc Dis 17:95-100, 2008

87. Summers SM: Transverse sinus thrombosis with hemorrhagic venous infarction treated with thrombectomy, endovascular tissue plasminogen activator, and systemic anticoagulation. J Emerg Med [epub ahead of print], 2009

88. Tarani L, Iacobini M, De Stefano V, Smacchia MP, Tozzi MC, Raguso G, et al: Recombinant plasminogen activator therapy for cerebral vein thrombosis in a child carrier of prothrombin gene mutation. J Pediatr Hematol Oncol 24:769-771, 2002

89. Towbin A: The syndrome of latent cerebral venous thrombosis: its frequency and relation to age and congestive heart failure. Stroke 4:419-430, 1973

90. Tsai FY, Higashida RT, Matovich V, Alfieri K: Acute thrombosis of the intracranial dural sinus: direct thrombolytic treatment. AJNR Am J Neuroradiol 13:1137-1141, 1992

91. Vines FS, Davis DO: Clinical-radiological correlation in cerebral venous occlusive disease. Radiology 98:9-22, 1971

92. Wasay M, Bakshi R, Kojan S, Bobustuc G, Dubey N, Unwin DH: Nonrandomized comparison of local urokinase thrombolysis versus systemic heparin anticoagulation for superior sagittal sinus thrombosis. Stroke 32:2310-2317, 2001

93. Weatherby SJ, Edwards NC, West R, Heafield MT: Good outcome in early pregnancy following direct thrombolysis for cerebral venous sinus thrombosis. J Neurol 250:1372-1373, 2003

94. Witham TF, Nemoto EM, Jungreis CA, Kaufmann AM: Nearinfrared spectroscopy monitored cerebral venous thrombolysis. Can J Neurol Sci 26:48-52, 1999

95. Yamini B, Loch Macdonald R, Rosenblum J: Treatment of deep cerebral venous thrombosis by local infusion of tissue plasminogen activator. Surg Neurol 55:340-346, 2001

96. Zerah M, Patterson R, Hansen I, Briones M, Dion J, Renfroe $\mathrm{B}$ : Resolution of severe sinus vein thrombosis with super selective thrombolysis in a pre-adolescent with diabetic ketoacidosis and a prothrombin gene mutation. J Pediatr Endocrinol Metab 20:725-731, 2007

97. Zhang A, Collinson RL, Hurst RW, Weigele JB: Rheolytic thrombectomy for cerebral sinus thrombosis. Neurocrit Care 9:17-26, 2008

Manuscript submitted June 15, 2009.

Accepted July 17, 2009.

Address correspondence to: Maryam Rahman, M.D., Department of Neurosurgery, University of Florida, Box 10265, Gainesville, Florida 32610-0265. email: maryam.rahman@neurosurgery.ufl.edu. 